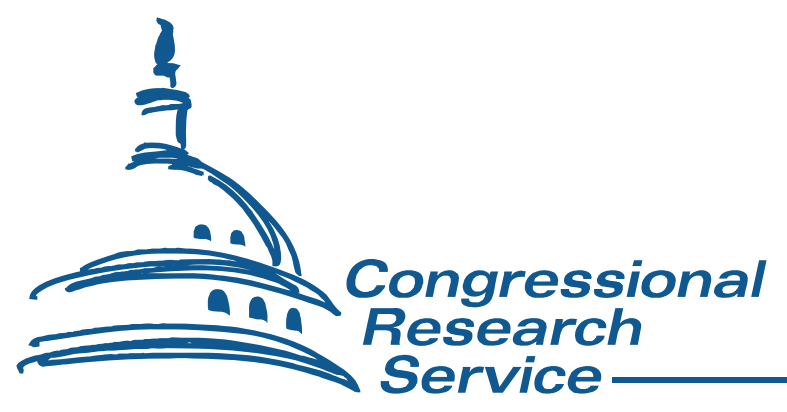

\title{
Crisis in Mali
}

\author{
Alexis Arieff \\ Analyst in African Affairs
}

January 14, 2013

Congressional Research Service 


\section{Summary}

For the past year, Mali has been mired in overlapping security, political, and humanitarian crises. Islamist extremist groups expanded their presence in the country's vast, Saharan north following a March 2012 coup d'état that overthrew Mali's democratically elected government and led the military chain of command to collapse. The insurgents include Al Qaeda in the Islamic Maghreb (AQIM), a U.S.-designated Foreign Terrorist Organization, along with at least two loosely allied groups. In the capital, Bamako, located in the south, the interim government formed in the wake of the coup has suffered from internal divisions and military interference, and must contend with an economic recession and revenue shortages. Insecurity in northern Mali has displaced over 350,000 people and exacerbated regional food insecurity and poor humanitarian conditions.

On January 11, 2013, France launched military operations against insurgent targets in northern Mali, following a request from the Malian government for help in repelling insurgent advances toward the south. French operations mark a sudden and major shift in international responses to the situation in Mali. Previously, international efforts had focused on a French-backed proposal for a West African-led military intervention, negotiations with some armed groups in the north, and prospects for elections aimed at a more legitimate, effective government in Bamako. The planned regional intervention, termed the African-led International Support Mission in Mali (AFISMA), was authorized by the U.N. Security Council in December 2012. However, AFISMA was widely seen as requiring many months to prepare. During the planning for AFISMA, serious questions have also been raised concerning Malian and regional troops' military capacity and will, as well as the potential cost and humanitarian consequences of regional deployments.

The United States may provide logistical support to ongoing French operations, as France has requested. The Obama Administration may also provide support to regional troop contributors as France and regional leaders attempt to accelerate African deployments under AFISMA. Prior to the French intervention, U.S. policymakers had reportedly debated the potential for unilateral action against terrorist actors in Mali. The Obama Administration has also called for Mali to organize national elections, and has supported regional efforts to mediate a way out of Mali's political standoff and contain violent extremism from spreading more widely in the region.

Congress plays a role in shaping U.S. policy toward Mali through its authorization and appropriation of foreign aid and defense programs, and through its oversight activities. Direct U.S. assistance to the Malian security forces - in addition to several other types of foreign aidhas been suspended in line with congressionally mandated restrictions triggered by the coup, which was led by a prior participant in a U.S. training program. The aid restrictions do not affect humanitarian assistance, of which the United States is the leading bilateral donor in the region.

The situation in Mali challenges U.S. goals of promoting stability, democracy, civilian control of the military, and effectively countering terrorist threats in Africa. It also raises questions regarding the strategic design and effectiveness of previous U.S. efforts to do so. Looking forward, Congress may consider issues related to how, and to what extent, to support French and regional military deployments to Mali; whether unilateral U.S. action is required or wise; how to assess previous U.S. security engagement in Mali and the region; and future U.S. aid, including humanitarian assistance. Congress may also consider the possible implications of the situation in Mali for broader U.S. counterterrorism and good governance efforts in Africa and beyond. 


\section{Contents}

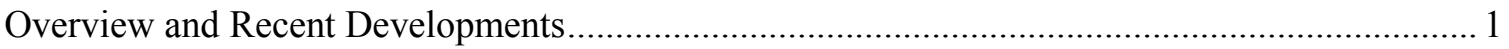

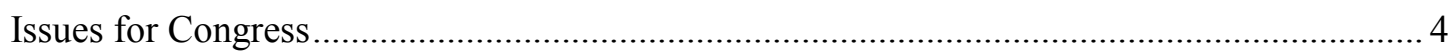

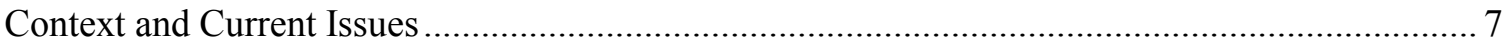

Assessing AQIM and Associated Extremist Groups .......................................................... 9

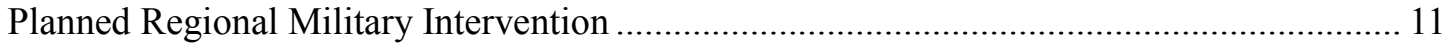

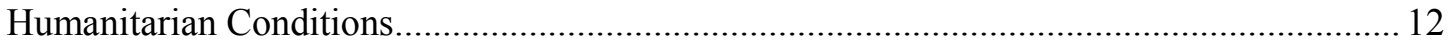

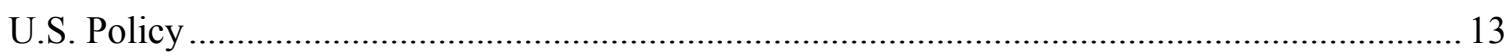

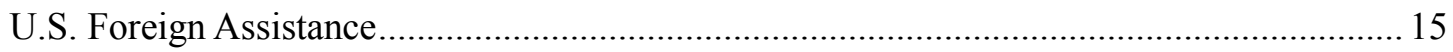

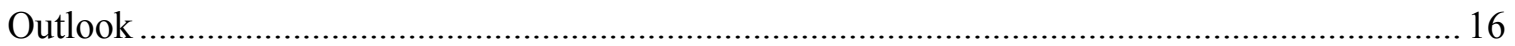

\section{Figures}

Figure 1. Map of Population Displacements and Insurgent Group Concentrations as of

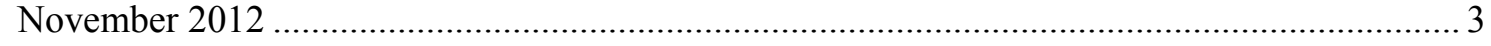

Figure 2. Mali: Timeline of Selected Recent Events ............................................................... 5

\section{Contacts}

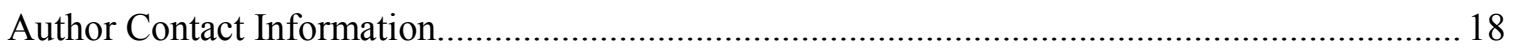

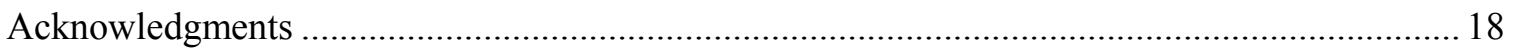




\section{Overview and Recent Developments}

For the past year, Mali has been mired in overlapping security, political, and humanitarian crises. After Mali's government was overthrown in a military coup in March 2012, insurgents, capitalizing on the ensuing power vacuum, seized much of the country's vast and sparsely populated northern territory. As of early January 2013, three loosely connected Islamist extremist groups - including Al Qaeda in the Islamic Maghreb (AQIM), a U.S.-designated Foreign Terrorist Organization-reportedly controlled all major towns in the north, an area roughly the size of Texas (see map, Figure 1, below). While the number of Islamist insurgent combatants appears to be small, they have become increasingly entrenched, ousting an ethnic Tuareg separatist group with which they were initially allied and recruiting adherents among local populations. ${ }^{1}$ Meanwhile, the post-coup, nominally civilian-led government in Bamako has been weakened by internal divisions and military interference, while years of corruption and mismanagement appear to have hollowed out many state institutions. Mali's leaders also face stark economic constraints amid a national recession and revenue crisis. ${ }^{2}$ A regional food security crisis, exacerbated by population displacements from northern Mali, also continues to cause suffering.

On January 11, 2013, France launched military air strikes and ground operations against insurgent targets in northern Mali after Islamist fighters - following months of stalemate - suddenly advanced toward the south and defeated Malian military forces in the town of Konna. The United States is sharing information with French forces and is also considering providing logistics and surveillance. The United Kingdom and other European states are also providing support. ${ }^{3}$ French President François Hollande has justified the intervention based on the Malian government's request for assistance, portraying the intervention as necessary to prevent the Malian capital from falling into terrorist hands, and additional French deployments in Bamako as helping to protect some 6,000 French citizens. ${ }^{4}$ French troop reinforcements in Bamako may also be aimed at deterring actors who might try to further destabilize or attack Mali's interim government.

French Foreign Minister Laurent Fabius stated on January 13 that the duration of French operations was "a question of weeks." At the same time, news reports have indicated that the extremist insurgents are better trained and equipped than French forces anticipated. ${ }^{5}$ In addition, given that the Malian military is internally divided, lacks the capacity to effectively project force, has been implicated in human rights abuses, and is very small (totaling some 7,000 troops prior to the defections and military defeats of the past year), it is uncertain whether Malian forces will be able to effectively follow up on French military strikes by securing and holding territory. In a radio interview, Oumar Ould Hamaha, a Malian insurgent commander who has been associated

\footnotetext{
${ }^{1}$ This report uses the term Tuareg to refer to the internally diverse ethnic community in the Sahara/Sahel whose members refer to themselves as Kel Tamasheq. The Tuareg separatist National Movement for the Liberation of Azawad (MNLA) was formed in 2011, when Tuareg combatants returning to Mali from Libya joined with other former rebels. The MNLA initially reportedly fought alongside elements of the Malian extremist group Ansar al Deen and of AQIM; however, since July, the Islamist armed groups have largely defeated the MNLA's forces.

${ }^{2}$ See Earl Gast, USAID Assistant Administrator for Africa, testimony before the House Foreign Affairs Subcommittee on Africa, Global Health, and Human Rights, June 29, 2012; and International Crisis Group (ICG), Mali: Pour une action internationale résolue et concertée, September 24, 2012.

${ }^{3}$ Associated Press (AP), "US Helping Support French Mali Operation" and Reuters, "U.S. Sharing Intelligence on Mali With France, Eyes Other Support,” January 14, 2013.

${ }^{4}$ French Presidency, "Déclaration du Président de la République sur la situation au Mali," January 11, 2013.

${ }^{5}$ Agence France Presse (AFP), “'Mali Islamists Much Stronger Than Expected,' France Says,” January 13, 2013;
} 
with all three main Islamist extremist groups in the north, threatened France with "a trap which is much more dangerous than Iraq, Afghanistan, or Somalia.",

The French operations mark a major shift in the context of international responses to the situation in Mali. Previously, efforts had focused on a French-backed proposal for a regional military intervention to support Malian efforts to retake the north, on negotiations with some armed groups in the north, and on prospects for forging a more legitimate, effective government in Bamako. The proposed regional force, dubbed the African-led International Support Mission in Mali (AFISMA), was authorized to assist in training the Malian security forces and to support them in recovering and stabilizing northern territory, under U.N. Security Council Resolution 2085 on December 20, 2012. However, a regional deployment was widely seen as requiring many months to prepare, pending anticipated internationally assisted training and restructuring of the Malian military, which was expected to lead operations to retake the north. Serious questions have also been raised concerning regional troops' military capacity, commitment, and human rights records, as well as the potential cost and humanitarian consequences of such an operation. AFISMA deployments are now being accelerated in the context of French operations. News reports have estimated AFISMA's potential cost at \$200 million-\$500 million.

Prior to French intervention, regional and Western leaders had warned of a rising threat to international security associated with an expansion of AQIM's influence and scope of operations in Mali, a possible spread of violent extremist ideology, and state fragmentation. The main armed Islamist groups in the north-AQIM, Ansar al Deen (or, Ansar al Dine, "Defenders of the Faith"), and the Movement for Unity and Jihad in West Africa (MUJWA, a.k.a. MUJAO after its French acronym) - appear to coordinate their actions and share personnel. Reports of foreign fighters from elsewhere in Africa and beyond have heightened concerns, as have reported links between the extremists and transnational smuggling networks, including drug traffickers. ${ }^{7}$

A U.N. report estimated the total number of "core combatants" of the armed groups in northern Mali at "around 3,000" adding that insurgents were actively recruiting and had "relatively sophisticated equipment obtained from Libya" and from Malian stocks. ${ }^{8}$ Other reports have estimated extremist forces at 4,000-6,000 or up to 15,000 combatants. ${ }^{9}$ Extremist groups have imposed harsh behavioral and dress codes on local residents in the north and have carried out amputations and executions, inspired by an extremely conservative interpretation of sharia (Islamic law). They have also targeted historic and cultural sites, including UNESCO World Heritage-designated ancient mosques and tombs; recruited child soldiers; and committed other abuses. Mali's security forces, who reportedly suffer from internal divisions and lack of capacity, have also been implicated in serious abuses, including torture and disappearances. ${ }^{10}$

\footnotetext{
${ }^{6}$ Steven Erlanger, Alan Cowell, and Adam Nossiter, "Malian Town Falls to Islamist Rebels, France Says, The New York Times, January 14, 2013.

${ }^{7}$ Mali-like other countries in West Africa-is reportedly a regional transit point in the flow of cocaine between South America and Europe. Some reports reference possible AQIM involvement in the trafficking. See, for example, the Mali country report in State Department, 2012 International Narcotics Control Strategy Report (INCSR), March 7, 2012.

${ }^{8}$ Report of the Secretary-General on the Situation in Mali, U.N. doc. S/2012/894, November 29, 2012.

9 “Mali: Report on Jihadists' Military Capabilities, Weapons," Jeune Afrique, November 12, 2012; "French Endeavor to Convince Algerian Leader of Mali-based Terrorist Threat," Le Canard Enchaîné, December 12, 2012; both via U.S. government Open Source Center.

${ }^{10}$ See Human Rights Watch (HRW), Testimony of Corinne Dufka before the Senate Foreign Relations Committee, “Addressing Developments in Mali: Restoring Democracy and Reclaiming the North,” December 5, 2012.
} 
Figure I. Map as of January II, 2013

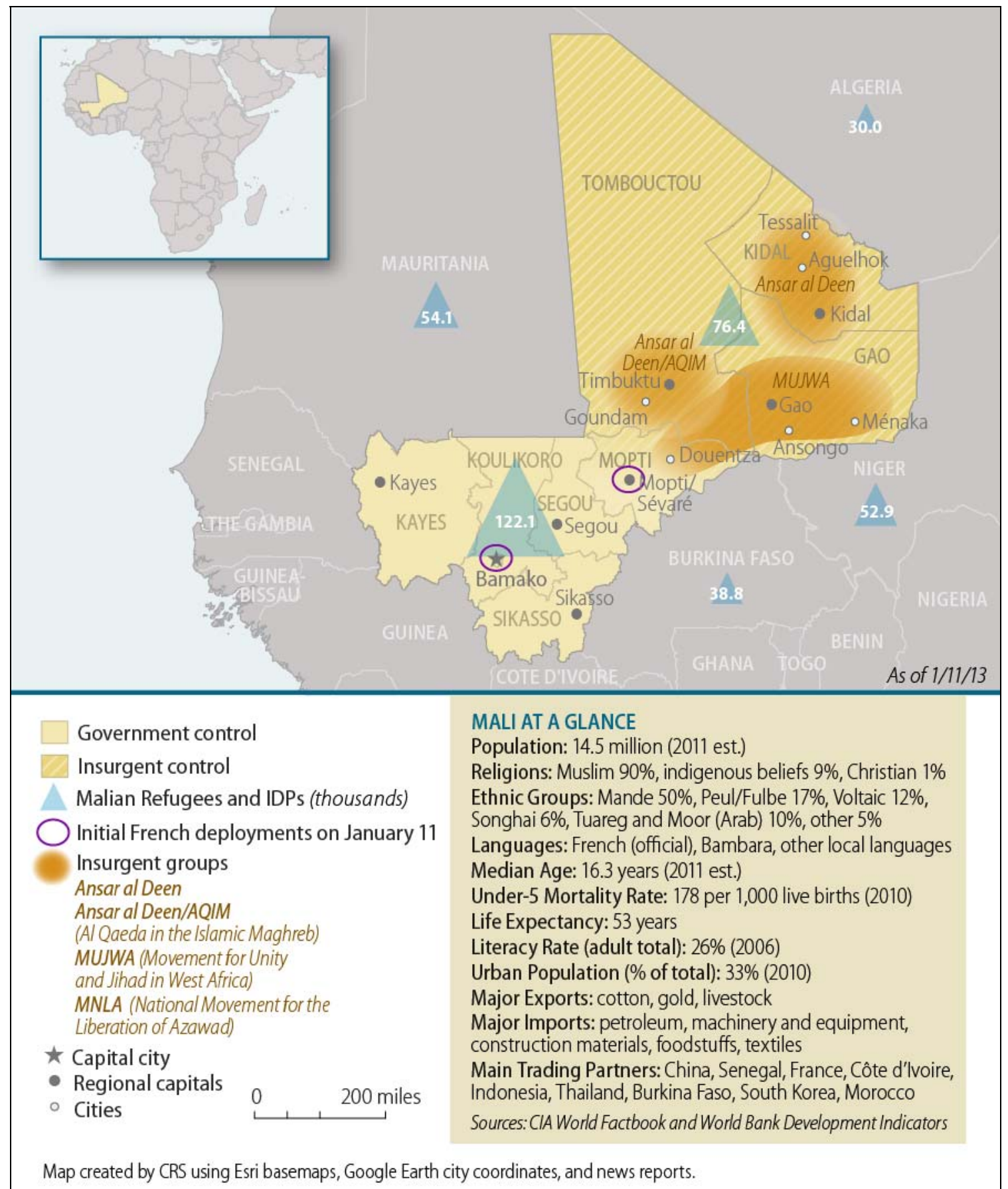

Source: CRS. Basemap created by Hannah Fischer using Esri Data 2012. Projection: Winkle II, November 29, 2012. Sources of information depicted include U.N. High Commissioner for Refugees (UNHCR) data, U.S. Agency for International Development (USAID) humanitarian updates, news reports, and CRS interviews.

Notes: Insurgent group concentrations are approximate and shifting - particularly in the context of French military operations - and are based on open-source accounts. IDP refers to Internally Displaced Persons. 


\section{Issues for Congress}

Congress plays a key role in shaping U.S. policy toward Mali through its authorization and appropriation of foreign aid and defense programs, and through its oversight. Bilateral security assistance to the Malian military has been suspended in line with congressionally mandated restrictions triggered by the coup. U.S. support for French and regional military operations could prompt the reallocation of resources previously appropriated by Congress for other aims, and/or a request for new funding. Congress may also assess prior U.S. security engagement in Mali and the wider region, and examine the implications of various policy options in Africa and beyond.

The evaluation of the threat posed by AQIM and affiliated groups may well be a key factor driving the U.S. approach to northern Mali. The Sahel has historically been seen as peripheral to core U.S. interests, although U.S. security engagement has grown over the past decade, and concerns have grown in light of ongoing political change and uncertainty in North Africa. News reports in 2012 claimed that the Obama Administration was contemplating unilateral strikes in northern Mali, reportedly prompting a debate over whether such strikes would require new legal authorization from Congress. ${ }^{11}$ While a delay in confronting the groups in Mali could have served to their advantage, a military response also carries significant risks. Besides being operationally challenging due to the harsh and remote Saharan terrain, military action could provoke otherwise noncohesive groups to rally around anti-southern or anti-Western sentiment, to boost recruitment, or to launch new attacks on Western or regional targets. The insurgents' response to French (and potentially other international) operations remains to be seen, as does the Malian military's ability and will to capitalize on outside assistance.

The United States is the leading provider of humanitarian aid in response to the regional food security crisis, and has allocated $\$ 119.3$ million over the past year for drought- and conflictaffected Malians. The issue of humanitarian access could rise on the international policy agenda if armed groups in northern Mali turn against aid agencies, or if concerns arise over the potential diversion of aid to terrorist groups. ${ }^{12}$ Prior to direct French intervention, humanitarian and human rights groups had warned of the potential negative humanitarian consequences of a military intervention by neighboring states in northern Mali. ${ }^{13}$

Before the coup, successive U.S. Administrations and many nongovernment observers viewed Mali as a democratic success, despite governance challenges - particularly in the north - and indications that the Malian public increasingly resented perceived state corruption and cronyism. Mali has been a longtime recipient of U.S. development aid, with modest gains achieved by health, education, and food security programs. U.S. military professionalization training emphasized civilian control and respect for human rights. Developments over the past year may bring into question the effectiveness of these programs and have jeopardized joint U.S.-Malian accomplishments in all of these areas.

\footnotetext{
${ }^{11}$ There have been unconfirmed reports of air strikes of unidentified origin in the north. On U.S. policy deliberations, see, e.g., Greg Miller and Craig Whitlock, "White House Secret Meetings Examine al-Qaeda Threat in North Africa," The Washington Post, October 1, 2012; Kimberly Dozier, "White House Widening Covert War in North Africa," Associated Press, October 2, 2012; and Julian E. Barnes and Evan Perez, "Terror Fight Shifts to Africa," Wall Street Journal, December 7, 2012.

${ }^{12}$ Such dynamics have challenged U.S.-funded humanitarian efforts in Somalia. See CRS Report R42046, Horn of Africa Region: The Humanitarian Crisis and International Response, coordinated by Rhoda Margesson.

${ }^{13}$ HRW, "Mali: Rising Ethnic Tensions Threaten New Violence," op. cit.; BBC, "Mali Intervention by ECOWAS: Refugee Fears," December 14, 2012.
} 
Figure 2. Mali:Timeline of Selected Recent Events

\begin{tabular}{|c|c|c|c|c|c|c|c|c|c|c|c|}
\hline $\begin{array}{l}\text { November } 2 \\
\text { Five Europea } \\
\text { kidnapped by } \\
\text { in two incide } \\
\text { northern and } \\
\text { Mali. A Germ } \\
\text { tourist is kille }\end{array}$ & $\begin{array}{l}\text {-25. } \\
\text { ns } \\
\text { AQIM } \\
\text { ts in } \\
\text { eastern } \\
\text { an } \\
\text { d. }\end{array}$ & \multicolumn{2}{|c|}{$\begin{array}{l}\text { February. U.S. } \\
\text { Defense Department } \\
\text { cancels annual } \\
\text { regional military } \\
\text { exercise due to be } \\
\text { held in Mali. U.S. } \\
\text { military airdrops } \\
\text { supplies to besieged } \\
\text { Malian troops in } \\
\text { Tessalit. }\end{array}$} & \multicolumn{2}{|c|}{$\begin{array}{l}\text { March 29-April } 2 . \\
\text { MNLA, fighting } \\
\text { alongside Islamist } \\
\text { Ansar al Deen } \\
\text { militants, seizes } \\
\text { control of the north. } \\
\text { AQIM commanders } \\
\text { appear in public in } \\
\text { Timbuktu. }\end{array}$} & \multicolumn{2}{|c|}{$\begin{array}{l}\text { May 1-2. Clashes } \\
\text { between junta } \\
\text { forces and } \\
\text { commandos loyal to } \\
\text { deposed president } \\
\text { lead to reports of } \\
\text { human rights } \\
\text { abuses meted out } \\
\text { by forces loyal to } \\
\text { Sanogo. }\end{array}$} & $\begin{array}{l}\text { May 22. Interim } \\
\text { President Traore } \\
\text { beaten by } \\
\text { protesters and } \\
\text { departs for } \\
\text { treatment in } \\
\text { France, leaving a } \\
\text { power vacuum in } \\
\text { Bamako. Traore } \\
\text { doesn't return until } \\
\text { late July. }\end{array}$ & $\begin{array}{l}\text { September. Mali's } \\
\text { government for } \\
\text { first time explicitly } \\
\text { calls for } \\
\text { international } \\
\text { support for military } \\
\text { operations in the } \\
\text { north. MUJWA } \\
\text { advances south to } \\
\text { take Douentza. }\end{array}$ & $\begin{array}{l}\text { December } 11 . \\
\text { Prime Minister } \\
\text { Cheick Modibo } \\
\text { Diarra arrested on } \\
\text { Sanogo's orders, } \\
\text { resigns. Traore } \\
\text { appoints Diango } \\
\text { Cissoko to } \\
\text { replace Diarra. }\end{array}$ & $\begin{array}{l}\text { December } 20 . \\
\text { U.N. Security } \\
\text { Council } \\
\text { Resolution } \\
2085 \\
\text { authorizes } \\
\text { African-led } \\
\text { International } \\
\text { Support } \\
\text { Mission in Mali } \\
\text { (AFISMA). }\end{array}$ \\
\hline $\begin{array}{l}\text { October } 2011 . \\
\text { Tuareg } \\
\text { combatants } \\
\text { return to Mali } \\
\text { from Libya. } \\
\text { National } \\
\text { Movement for } \\
\text { the Liberation of } \\
\text { Azawad (MNLA) } \\
\text { is formed. }\end{array}$ & \multicolumn{2}{|c|}{$\begin{array}{l}\text { January } 2012 \text {. } \\
\text { Massacre of Malian } \\
\text { troops and civilians } \\
\text { at Aguelhok } \\
\text { reportedly exhibits } \\
\text { signs of AQIM } \\
\text { involvement. Malian } \\
\text { military wives march } \\
\text { on Bamako to } \\
\text { protest poor } \\
\text { conditions of troops. }\end{array}$} & \multicolumn{2}{|c|}{$\begin{array}{l}\text { March 21-22. Junior } \\
\text { officer mutiny spirals } \\
\text { into coup d'etat } \\
\text { headed by Capt. } \\
\text { Amadou Sanogo. } \\
\text { ECOWAS calls for } \\
\text { return to constitutional } \\
\text { order, threatens } \\
\text { sanctions. }\end{array}$} & \multicolumn{2}{|c|}{$\begin{array}{l}\text { April 6-12. MNLA } \\
\text { declares independent } \\
\text { state. Divisions among } \\
\text { armed groups } \\
\text { increasingly apparent. } \\
\text { ECOWAS brokers } \\
\text { agreement in which the } \\
\text { junta will cede power to } \\
\text { a civilian government } \\
\text { lead by Dioncounda } \\
\text { Traore, former speaker } \\
\text { of parliament. }\end{array}$} & & $\begin{array}{l}\text { ECOWAS } \\
\text { ment in } \\
\text { Sanogo is } \\
\text { ed status of } \\
\text { head of } \\
\text { and Traore } \\
\text { ule for a year } \\
\text { to elections. }\end{array}$ & $\begin{array}{l}\text { June. MUJWA, an } \\
\text { AQIM splinter } \\
\text { faction, ousts } \\
\text { MNLA from key } \\
\text { city of Gao. MNLA } \\
\text { increasingly in } \\
\text { retreat in the north. }\end{array}$ & $\begin{array}{l}\text { December } 10 . \\
\text { European Union } \\
\text { approves } \\
\text { concept for a } \\
\text { mission to train } \\
\text { and restructure } \\
\text { the Malian } \\
\text { security forces. }\end{array}$ & $\begin{array}{l}\text { January 11, } \\
\text { 2013. France } \\
\text { launches } \\
\text { military } \\
\text { operations in } \\
\text { northern Mali. }\end{array}$ \\
\hline
\end{tabular}

Sources: News accounts, multilateral organization reports, CRS interviews.

Note: Further analysis of recent events is available from CRS on request. 


\section{Background on Mali}

Politics. Mali peacefully gained independence from France in 1959, initially as part of a short-lived federation with Senegal. Founding President Modibo Kéita installed a one-party, socialist-leaning dictatorship. In 1968, Kéïta was ousted in a military coup by Moussa Traoré, who went on to serve as president for over two decades. (Former Prime Minister Modibo Diarra, who resigned on December II, is Traoré's son-in-law.) Starting in 1989, Malians increasingly began calling for multiparty democracy, echoing movements that emerged across Africa at the end of the Cold War. In 199I, Amadou Toumani Touré (popularly known as ATT) overthrew Traoré in a military coup and organized democratic elections. Longtime opposition activist Alpha Oumar Konaré was elected president. Mali's growing reputation for democratic rule was enhanced in 2002, when Konaré stepped down at the end of two constitutionally permitted terms, and ATT, running as an independent and leveraging his reputation as Mali's "soldier of democracy," was elected president. It was Mali's first democratic transition between civilian leaders.

ATT, who was reelected in 2007, pursued a broad and flexible ruling coalition and a style that he referred to as "consensus" politics, in the absence of clear ideological preferences or platforms among political parties. This system appears to have incentivized corruption and patronage among political elites, or at least contributed to public perceptions that the system was corrupt. Civil society, likewise, largely revolved around the centers of political power and state patronage. As of early March 2012, the future of the "consensus" system was uncertain, given ATT's stated determination to step down once elections scheduled for April 2012 were held, and his lack of a clear successor. Anxiety over an anticipated political vacuum may have explained speculation in the local press that ATT-despite all reports to the contrary-was plotting to prolong his time in office on the pretext of insecurity in the north. ${ }^{14}$

The Tuareg Issue. Members of the semi-nomadic and diverse Tuareg community, who inhabit parts of Mali, Niger, Burkina Faso, Algeria, and Libya, have periodically rebelled against the Malian state. (Tuaregs have also rebelled periodically in neighboring Niger.) Tuaregs are a small minority within Malian society, although no precise population figures are available. Tuareg rebel groups have claimed greater control over what they see as their historic homeland in the north, which they refer to as Azawad. At times, Azawad has been defined to include Tuareg areas across the region. They have also complained of neglect and discrimination by the Malian government, which has been dominated by southern ethnic groups since independence. Most recently, negotiated settlements in the early 1990s and 20062009-mediated by the government of Algeria_laid the groundwork for fragile peace by promising greater regional autonomy, the integration of Tuareg combatants into the military, and more state aid for the impoverished north. The government never fully implemented these agreements, and nonimplementation became a grievance unto itself. Prospective control over potential oil and gas resources in northern Mali may have fueled conflict as well.

Islam in Mali. Mali's population is $90 \%$ Muslim, with animist and Christian communities making up the remaining $10 \%$. The pre-colonial empires of current-day Mali played a key role in the spread of Islam in West Africa. Notably, the Saharan city of Timbuktu, then a vital cross-roads of regional commerce, was a major center of Islamic scholarship between the $12^{\text {th }}$ and $16^{\text {th }}$ centuries. The Malian state is secular (although it plays a role in regulating religious activities), and moderate approaches to Islamic beliefs are generally predominant. Yet, more radical and conservative views have also increased in recent years. ${ }^{15}$ In 2005, the International Crisis Group warned that although, in its view, the risk of Islamist extremism in West Africa had been overstated by some Western policymakers, Mali "runs the greatest risk of any West African country other than Nigeria of violent Islamist activity." 16 While this risk is currently on display most vividly in the north, it has also affected politics in Bamako. For example, in 2009, a draft family code that would have expanded and guaranteed a number of women's rights was fiercely opposed by Malian civic and religious groups, despite being a signature initiative of then-President Touré. The enacted version was revised to reflect input from religious leaders, and lacked many of the more progressive provisions of the first version.

\footnotetext{
${ }^{14}$ See, e.g., Kader Toé, “Intime conviction : La République poignardée par ses privilégiés,” Le Matin, March 22, 2012.

15 "Bamako Under Growing Pressure From Islamist Thinking, Practices," Libération (France) via U.S. government Open Source Center (OSC), June 4, 2012. The conservative Salafist movement has been present in Mali for over 60 years, and has reportedly made the greatest inroads among urban populations and in those recently converted to Islam. See Dimensions transnationales de l'islam africain et mutations contemporaines du Sahel, study prepared for the French Ministry of Defense by Sciences Po-Bordeaux, March 2011.

${ }^{16}$ ICG, Islamist Terrorism in the Sahel: Fact or Fiction?, March 31, 2005.
} 


\section{Context and Current Issues}

Mali's instability stems from both internal and external factors. These include poor governance, the corrosive impact of drug trafficking and other illicit commerce, military fragmentation and collapse, limited implementation of previous peace accords with Tuareg rebel groups, and an uptick in regional arms and combatant flows from Libya since 2011. High-level corruption, reportedly tied, in part, to criminal networks, contributed to public distaste for the government and to reported initial support for the coup against former President Amadou Toumani Touré. ${ }^{17}$

The Economic Community of West African States (ECOWAS) has attempted, with mixed results, to induce Mali's military to stop interfering in politics and to empower a fragile civilian-led transitional government. The regional body, through its appointed mediator on Mali, President Blaise Compaoré of Burkina Faso, has also facilitated negotiations between the Malian government and two northern armed groups: the Tuareg separatist National Movement for the Liberation of Azawad or MNLA, which started the 2012 conflict that led to the current spiral of events; and Ansar al Deen, a Malian-led Islamist extremist group. The government of Algeria has also held talks with these groups. However, prospects for productive negotiations with Ansar al Deen would appear to be annulled by recent developments. More broadly, ECOWAS and African Union (AU) efforts to forge a response to Mali's crisis have been hampered by regional divisions, rivalries, and a lack of planning and military capacity.

Rank and file soldiers blamed corruption and mismanagement for defeats at the hands of Tuareg rebels in early 2012. Such sentiment may have been the proximate driver of the 2012 coup, but military dysfunction runs much deeper. The roughly 7,000-person military remains in disarray due to internal tensions and political uncertainty. The military's personnel levels and equipment stocks were eroded by defections (namely of Tuareg troops who defected to the MNLA in early 2012), desertions, and the collapse of the operational command in the north in the first half of 2012. In recent months, the military has initiated a recruitment drive and has reportedly provided support to allied irregular militias, which are organized largely along ethnic lines. ${ }^{18}$ Factionalization of the military and police has been illustrated by violent clashes, disappearances, and other abuses carried out within the security forces. Soldiers in the south have also been accused of extrajudicial killings of conservative religious activists and Tuaregs. ${ }^{19}$

Coup leader Capt. Amadou Sanogo - previously a relatively obscure military language instructor who received U.S. training - holds no formal position in the government, but continues to wield significant influence. This was starkly illustrated on December 11, when interim Prime Minister Cheick Modibo Diarra resigned after Sanogo ordered his arrest. ${ }^{20}$ Interim President Dioncounda

\footnotetext{
${ }^{17}$ A 2010 United Nations Development Program (UNDP) study noted that "even though it is not a recent phenomenon, corruption seems to have worsened with the democratization process, higher levels of development assistance and the growth of the private sector... In addition, the search for compromise, which characterizes the social, political and economic life in Mali, has generated a culture of tolerance and impunity." Mali: Réforme de l'administration publique, accès à l'information et gouvernance électronique, 2010. Some observers have posited that U.S. military aid fueled corruption, although this is difficult to assess. Africa Confidential, "Mali : Rebels and Putschists," March 30, 2012.

${ }^{18}$ On the militias, see Amnesty International, "Mali: Civilians Bear the Brunt of the Conflict," op. cit., which, among other things, accuses the militias of recruiting child soldiers.

${ }^{19}$ Rukmini Callimachi, "Massacre of Preachers in Mali Sign of Broken Army,” AP, September 22, 2012; and Corinne Dufka (HRW) testimony, Senate Foreign Relations Subcommittee on African Affairs, December 5, 2012.

${ }^{20}$ Sanogo accused Diarra of obstructing the workings of the interim government in the service of his own political ambitions. Some observers speculated that Diarra's support for a regional military intervention, which is reportedly (continued...)
} 
Traoré appointed Diango Cissoko, a veteran public servant, to replace Diarra. Sanogo also heads an official commission on security sector reform, placing him in a position to influence the allocation of international military aid aimed at restructuring Mali's security forces.

ECOWAS's decision to authorize the current interim government through April 2013 presents a policy dilemma. On the one hand, elections may be seen as necessary to form a government able to make credible commitments in negotiations with Malian-led armed groups and/or command military operations in the north. On the other hand, the idea of holding elections without the north is controversial, and the conditions under which credible elections could take place are uncertain. Preparations for elections - which, had the coup not intervened, were due to take place in April 2012 - have nominally begun, but no election date has been set. In 2011, an assessment by U.S.based democracy organizations pointed to "widespread political disengagement and Malian citizens' increasingly evident dissatisfaction with the state of their country's nascent democracy." ${ }^{21}$ A long-running process of government decentralization, aimed at enhancing state responsiveness and service-delivery, has also never been fully implemented. This has contributed to northern grievances and may undermine the impact of national-level elections.

Tuareg grievances over cultural rights, political autonomy, and a historic lack of government investment in the north - which prompted, in part, the independence rebellion that set off the current spiral of events - remain relevant for many northern Malians. Yet the Tuareg community is internally diverse, and divided over issues of political Islam and ethnic separatism. ${ }^{22}$ Moreover, Tuaregs are a minority even within the north. Often acrimonious inter-ethnic relations represent an additional challenge to finding a durable, comprehensive solution to Mali's ailments. ${ }^{23}$ Plans for "national consultations" aimed at forging consensus on a road map for political transition and reintegration of the north have been slow to advance. The secular structure of the post-colonial Malian state, in a country that is over $90 \%$ Muslim, could also be up for negotiation should national consultations materialize.

Among the Sahel states most affected by AQIM (Mali, Niger, and Mauritania), Mali has long been seen as the least willing or militarily able to counter the group's presence. This may have reflected the relative prioritization of scarce state resources, or calculations that an increased military presence in the north would be destabilizing given the region's history of Tuareg rebellions. Some analysts have posited a tacit agreement between the Malian state and AQIM,

\footnotetext{
(...continued)

opposed by Sanogo and some other members of the military, played a part as well. Many analysts agree that Diarra was playing an obstructive role, but note that Sanogo's actions bode ill for efforts to distance the military from politics.

${ }^{21}$ International Republican Institute (IRI), International Foundation for Electoral Systems (IFES), National Democratic Institute (NDI), and Internews, "CEPPS Mali 2012 General Elections Support: Pre-Election Assessment Report," July 8, 2011. CEPPS refers to the Consortium for Elections and Political Process Strengthening, a cooperative agreement under which contracts for most USAID contracts for support to elections and political processes are negotiated. Voter turnout in the past decade has hovered around $30 \%-40 \%$.

${ }^{22}$ Tuareg communities have generally adhered to a moderate form of Islam, and at times, Tuareg rebel movements have portrayed themselves as best placed to fight Islamist militancy in the Sahel. At the same time, AQIM has long had links to Tuareg smuggling networks in northern Mali, and religious ideology varies considerably within Tuareg communities. The Malian Islamist extremist group Ansar al Deen is led by Iyad ag Ghali, a leading figure in previous Tuareg rebellions who also has longstanding connections to AQIM. See Baz Lecocq, Disputed Desert: Decoloniasation, Competing Nationalisms and Tuareg Rebellions in Northern Mali, Boston: Brill, 2010.

${ }^{23}$ Historically tense - if co-dependent-relations among ethnic groups in the north have worsened due to recent cycles of interethnic violence coinciding with previous Tuareg rebellions. On current dynamics, see HRW, "Mali: Rising Ethnic Tensions Threaten New Violence," December 20, 2012.
} 
under which the government did not vigorously pursue AQIM while, in return, AQIM did not directly threaten Bamako. ${ }^{24}$ Still, AQIM attacks and kidnappings within Mali escalated in the second half of 2011, as did Malian military operations against the group.

\section{French Policy on Mali}

France's urgent focus on Mali appears to stem from an assessment that AQIM and affiliated groups pose a direct security threat. AQIM has kidnapped French nationals and threatened attacks in Europe; France declared "war" on the group in 2010 following a failed French attempt to rescue AQIM-held hostages. ${ }^{25}$ Recent fears could center on concerns that French citizens-including dual nationals hailing from France's sizable West African immigrant populations - could be drawn to fight with AQIM and allied groups in northern Mali, and/or receive AQIM training or financing to perpetrate terrorist attacks in France or against French interests. AQIM and other extremist groups in the Sahel reportedly hold eight French hostages-four kidnapped in northern Niger in 2010, two in northeastern Mali in 20II, one in western Mali in November 2012, and one in northern Nigeria in December 2012.

\section{Assessing AQIM and Associated Extremist Groups}

There are three main armed Islamist groups in northern Mali: Al Qaeda in the Islamic Maghreb or AQIM; Ansar al Deen (alt: Ansar al Dine, "Defenders of the Faith"), and the Movement for Unity and Jihad in West Africa (MUJWA, a.k.a. MUJAO after its French acronym). ${ }^{26}$ AQIM grew out of Algeria's civil conflict of the 1990s, and has been present in northern Mali for at least a decade. It has kidnapped Westerners, primarily Europeans and mostly for ransom, in Mali, Mauritania, Niger, and Algeria. AQIM has also carried out a number of bombings within Algeria, including against a U.N. office in Algiers in 2007. AQIM's leader, Abdelmalek Droukdel, is reportedly based in northeastern Algeria, although his whereabouts are uncertain; a news reporter claimed to have seen him in Timbuktu in mid-2012. ${ }^{27}$ The group has been a U.S.-designated Foreign Terrorist Organization for a decade. ${ }^{28}$

MUJWA, which emerged in late 2011 as a splinter faction of AQIM, has also carried out kidnappings in the region and terrorist attacks in Algeria. In December 2012, the United States named MUJWA and two of its leaders "Specially Designated Global Terrorists" under Executive Order $13224 .{ }^{29}$ Ansar al Deen, the third main extremist group in Mali, has not been designated as

\footnotetext{
${ }^{24}$ See, e.g., ICG, Mali: Avoiding Escalation, July 18, 2012, which states that collusion among actors within the government and AQIM "has seemed increasingly likely and has become the dominant doctrine in the foreign affairs departments of Western and neighboring countries."

${ }^{25}$ See Geoff D. Porter, “AQIM's Objectives in North Africa,” CTC Sentinel, February 1, 2011.

${ }^{26}$ Northern Mali also hosts a range of other armed groups, including an AQIM splinter faction led by a longtime AQIM Sahel-based commander, Mokhtar bel Mokhtar; elements of the Nigerian extremist group Boko Haram; Malian Arab militias; and armed bandits and smuggling networks. A new group referring to itself as Ansar al Sharia-a name used by Salafist groups in Libya, Tunisia, and elsewhere, with unclear ties to one another-emerged in late 2012, but its membership, structure, and relationship with other extremist groups in the north is uncertain.

${ }^{27}$ May Ying Welsh, "Mali: The 'Gentle' Face of al-Qaeda,” Al Jazeera, December 30, 2012. The extent to which Droukdel provides operational guidance or decision-making for AQIM as a whole is unclear.

${ }^{28}$ AQIM was first designated under its previous moniker, the Salafist Group for Preaching and Combat. It renamed itself AQIM in 2007. FTOs are designated by the Secretary of State in accordance with the Immigration and Nationality Act. The legal criteria are the following: (1) it must be a foreign organization; (2) it must engage in terrorist activities, as statutorily defined, or retain the capability and intent to engage in terrorist activity or terrorism; and (3) the organization's terrorist activity or terrorism must threaten the security of U.S. nationals or the national security of the United States. See State Department, Country Reports on Terrorism, at http:/www.state.gov/j/ct/rls/crt/index.htm.

${ }^{29}$ As a result of the designation, all property subject to U.S. jurisdiction in which MUJWA or the two designated individuals have any interest is blocked and U.S. persons are prohibited from engaging in any transactions with them or to their benefit. State Department, "Terrorist Designations of the Movement for Unity and Jihad in West Africa, Hamad (continued...)
} 
a terrorist group in the United States, and in 2012 U.S. officials expressed support for negotiations with its leaders. ${ }^{30}$ However, the U.S. assessment of Ansar al Deen may shift given the group's reported role in leading insurgent advances toward the south in January 2013, which prompted France's decision to launch military strikes in northern Mali.

Gauging AQIM's ultimate goals and capacities is particularly difficult due to widely reported internal divisions over strategy, leadership, and tactics. Similar divisions appear to characterize other extremist groups in the north, including MUJWA and Ansar al Deen. Generally, "AQIM" appears to refer to a loose affiliation of actors, who may not be bound by command or shared goals, and whose motivations and capabilities may diverge significantly. It is furthermore not clear what AQIM's connection with core Al Qaeda means in practice. ${ }^{31}$ Large-scale terrorist attacks by AQIM appeared to peak with a series of sophisticated bombings in Algiers in 2007; prior to the past year's events, its influence in the region had appeared to be waning.

Since early 2012, U.S. officials have been concerned that AQIM and affiliated groups could leverage their expanded presence in northern Mali to carry out training, expand recruitment, and advance transnational terrorist plots. Officials have pointed to links between AQIM and extremist groups in Libya, Nigeria, Somalia, Yemen, and elsewhere. Secretary of State Hillary Clinton and Deputy Assistant Secretary of Defense for African Affairs Amanda Dory have also suggested that those who carried out the September 11, 2012, attacks in Benghazi, Libya, had ties to AQIM. ${ }^{32}$ These reports are difficult to verify, as is the operational significance of potential contacts between AQIM and other extremist actors. Factions and allies of AQIM may nonetheless leverage the broader regional political and security situation created by ongoing upheaval and transitions in North Africa, as fragile transitional governments confront myriad security threats without the capacity or will to exercise their predecessors' style of authoritarian control.

AQIM has reportedly amassed significant wealth by holding kidnapped Westerners for ransom and through involvement in cross-border smuggling operations. This has led some U.S. defense officials to refer to it as "Al Qaeda's best funded, wealthiest affiliate." ${ }^{33}$ Still, estimates of the

\footnotetext{
(...continued)

el Khairy, and Ahmed el Tilemsi," December 7, 2012.

${ }^{30}$ State Department daily news briefing, November 7, 2012.

${ }^{31}$ The Combating Terrorism Center (CTC) at West Point, in its analysis of selected communications by Osama bin Laden, stated that "while there is mention of [AQIM] in the documents released to the CTC, these discussions are not substantive enough to inform an understanding of the relationship between al-Qa'ida's senior leaders and these groups." The CTC study also cites at least one appeal by Bin Laden for financial support from AQIM. Letters from Abbottabad: Bin Ladin Sidelined?, May 3, 2012.

${ }^{32}$ White House, "Deputy National Security Advisor for Counterterrorism and Homeland Security John Brennan Delivers Remarks at the Woodrow Wilson Center on Counterterrorism," April 30, 2012; Testimony of Matthew G. Olsen, Director, National Counterterrorism Center, before the Senate Homeland Security and Governmental Affairs Committee, September 19, 2012; and Rob Mergetta, "AFRICOM Commander Sees 'Troubling' Collaboration from Terror Groups,” Congressional Quarterly, December 4, 2012; among others. On AQIM's reported links to Boko Haram in Nigeria, see CRS Report RL33964, Nigeria: Current Issues and U.S. Policy, by Lauren Ploch Blanchard. The New York Times, "Clinton Cites Clear Link Between Al Qaeda and Attack in Libya," September 26, 2012; and Dory, testimony before the Senate Foreign Relations Subcommittee on African Affairs, December 5, 2012.

${ }^{33}$ David Lewis, “Al Qaeda's Richest Faction Dominant in North Mali-US,” Reuters, July 26, 2012. The State Department's 2011 Country Reports on Terrorism states, in contrast, that "AQIM is significantly constrained by its poor finances and lack of broad general appeal in the region." A 2011 report by the Financial Action Task Force (FATF) - an inter-government body for combating money laundering, terrorist financing, and related financial system threats - estimated that AQIM had collected at least $\$ 65$ million in kidnap-for-ransom payments since 2005, and cited "US and EU estimates" of AQIM's annual budget of approximately 15 million Euros (\$19.9 million) per year. These (continued...)
} 
group's resources vary, and the rate at which AQIM and affiliated groups are forced to spend money (e.g., on supplies, recruits, and local patronage networks) is unclear. Given AQIM's reported contacts with other extremist groups, U.S. officials appear concerned that AQIM could share its funds with other terrorist actors. ${ }^{34}$

AQIM's Sahel-based commanders - most, if not all, of whom are believed to be Algerian nationals - have reportedly cultivated extensive personal and business ties in northern Mali on pragmatic, ideological, and ethnic grounds. MUJWA and Ansar al Deen, which is led by a Malian Tuareg with longstanding reported ties to AQIM, have cultivated similar linkages with local populations. ${ }^{35}$ Ansar al Deen's stronghold is in the Tuareg-dominated Kidal region of far-northern Mali, while MUJWA appears to have leveraged anti-Tuareg sentiment in Gao to rally support from other ethnic communities, notably some Songhai/Peul groups who are the majority there.

\section{Planned Regional Military Intervention}

Preparations for planned regional troop deployments are now being accelerated in light of France's decision to intervene on January 11. U.N. Security Council Resolution 2085 authorized for one year an external military intervention in northern Mali-termed the African-led International Support Mission in Mali, or AFISMA - to help reunify Malian territory and combat extremist and criminal groups. The ECOWAS/AU proposal for the force envisions a 3,300-person deployment in support of a Malian military contingent of 5,000 troops, which would lead operations. In this context, the European Union (EU) is establishing a training mission to help restructure, reform, and build the capacity of the Malian security forces. ${ }^{36}$

AFISMA is not conceived as a full U.N. "blue helmet" operation. Instead, pending further Security Council deliberations, it is expected to be funded either through voluntary bilateral donor contributions, or potentially through a U.N.-funded logistics support package. News reports have cited estimates that the operation would cost \$200-500 million in its first year. ${ }^{37}$ Given the extremely limited ability of West African states to project military force, donors would presumably provide air lift, surveillance, equipment, and training to regional troop contributors. (France has reportedly transported some regional troops to Mali since the start of French military operations.) U.S. officials have expressed a qualified willingness to provide logistical support to AFISMA, for which France has provided the most vocal diplomatic support. (See "U.S. Policy.")

(...continued)

figures are a topic of debate, and AQIM outlays have presumably evolved along with its positioning in northern Mali. FATF, Organised Maritime Piracy and Related Kidnapping for Ransom, July 2011. See also CRS Report R41004, Terrorism and Transnational Crime: Foreign Policy Issues for Congress, by John Rollins and Liana Sun Wyler.

${ }^{34}$ Remarks of Under Secretary of the Treasury David Cohen at Chatham House on "Kidnapping for Ransom: The Growing Terrorist Financing Challenge," October 5, 2012.

${ }^{35}$ AQIM and MUJWA are led by "foreigners," i.e. Algerian and Mauritanian Arabs; however, both also incorporate substantial Malian contingents. Family and tribal ties also link Arab communities in the three countries and in Western Sahara. Tuareg communities have generally been portrayed as adhering to a moderate form of Islam, and at times, Tuareg rebel movements have portrayed themselves as best placed to fight Islamist militancy in the Sahel. At the same time, AQIM has long had links to Tuareg smuggling networks in northern Mali, and religious ideology varies considerably within Tuareg communities. See Baz Lecocq, Disputed Desert: Decoloniasation, Competing Nationalisms and Tuareg Rebellions in Northern Mali, Boston: Brill, 2010.

${ }^{36}$ The mission would reportedly comprise about 400 personnel, including 200 trainers. They are expected to deploy in early 2013. However, evolving security conditions may impact planning for the mission.

${ }^{37}$ Tim Witcher, “US Doubts African Military Intervention Plan for Mali,” Associated Press, December 6, 2012. 
Prior to the French intervention, some experts - including Romano Prodi, the U.N. SecretaryGeneral's special envoy on the Sahel- had suggested that AFISMA could take a year or more to deploy. ${ }^{38}$ In addition to a general lack of logistical and combat capacity among the countries in the region and the daunting logistics of carrying out a counter-insurgency mission in the Sahara, prospective regional troop contributors also face challenges related to a lack of shared language, doctrine, and interoperability.

Given its size, experience in counterterrorism, and military superiority in the region, Algeria's role in responding to Mali's security crisis has drawn intense international attention. Secretary of State Clinton traveled in October to Algeria, where bilateral discussions focused on the situation in Mali. Algeria's constitution prohibits troop deployments beyond its national borders, and noninterference in other states' sovereignty is a cornerstone of Algerian foreign policy. Still, Algeria could potentially provide support for a regional operation in other ways. Amid intense U.S. and French diplomatic pressure on Algeria to play a constructive role with regard to Mali, Algerian officials have oscillated between opposing and tacitly accepting the concept of regional military action. In part, Algerian objections may have stemmed from the perception that a regional deployment could serve as a front for Western intervention. Algerian leaders' preoccupation with domestic politics and the opacity of Algeria's decision-making apparatus have also complicated Algeria's claims to regional leadership in the Sahel. ${ }^{39}$

\section{Humanitarian Conditions}

Insecurity in Mali has aggravated a regional food security emergency. ${ }^{40}$ As of early January 2013, some 155,000 Malian refugees were in neighboring countries, while nearly 200,000 more Malians were displaced internally. U.N. agencies at that time estimated that 747,000 people in Mali were suffering from moderate to severe food insecurity and required immediate food assistance. Of these, approximately 510,000 were in the north. ${ }^{41}$ The implications of French military operations for humanitarian conditions and for aid workers are uncertain. Although aid groups have been able to work in the north through local staff and partner organizations, security threats to personnel have challenged aid delivery. Regional governments and humanitarian actors reportedly prepared contingency plans in case regional military deployments under AFISMA were to provoke a spike in population displacements, a reduction in access to vulnerable populations, or a possible halt to some humanitarian activities. ${ }^{42}$

On December 14, the United Nations announced a 2013 consolidated appeal (CAP) of $\$ 370$ million for Mali, reflecting proposed funding requirements from U.N. agencies, nongovernmental organizations, and other relief agencies for activities in the country in 2013. The appeal is aimed at funding assistance for nearly 4 million people in Mali affected by the food and nutritional crisis, including 1.5 million people in the north. The U.N. 2013 CAP of

\footnotetext{
${ }^{38}$ Reuters, "U.N. Envoy Rules Out International Action in Mali For Now," November 20, 2012.

${ }^{39}$ See CRS Report RS21532, Algeria: Current Issues; Laurence Aïda Ammour, Regional Security Cooperation in the Maghreb and Sahel: Algeria's Pivotal Ambivalence, Africa Center for Strategic Studies, February 2012; and Arieff, Algeria and the Crisis in Mali, Institut Français des Relations Internationales (IFRI), July 2012.

${ }^{40}$ The regional food crisis, which peaked in mid-2012, stems from a number of factors on top of the aforementioned structural issues, including a recent drought, high global food prices, and a drop in remittances from migrants due to the global economic slowdown and population inflows from Libya.

${ }^{41}$ U.S. Agency for International Development (USAID), Mali-Humanitarian Update \#5, January 3, 2013.

${ }^{42}$ USAID, Sahel: Food Insecurity and Complex Emergency, Fact Sheet \#1, November 6, 2012.
} 
approximately $\$ 1.5$ billion for the entire Sahel region represents a decrease from the $\$ 1.65$ billion requested in 2012. ${ }^{43}$ This reflects that fact that following the June-September regional rainy season, conditions in most parts of the Sahel have improved due to harvests, relative reductions in food prices, and increased income-generating opportunities for many farmers and pastoralists. ${ }^{44}$

\section{U.S. Policy}

The prospect of an expanded safe-haven for AQIM and other extremists and criminal actors in Mali is a principal concern for U.S. policymakers examining the situation in Mali and the wider region. The situation presents a threat to regional security; it may also threaten Western targets and interests in the region, and potentially beyond. Given France's decision to launch military strikes in Mali, the Obama Administration may choose to provide direct support to French operations and to accelerate plans to provide logistical support to regional forces expected to deploy under the U.N.-authorized AFISMA operation.

Prior to French military operations, Administration officials had emphasized that they were supporting African-led efforts to facilitate negotiations with some armed groups in the north and to prepare for proposed regional military operations against others. ${ }^{45}$ Administration officials had also indicated that they were approaching the various aspects of Mali's crisis - security, political, and humanitarian - simultaneously, and therefore declined to discuss challenges in sequencing or prioritizing components of the response. ${ }^{46}$ At the same time, according to media accounts, Administration officials had reportedly discussed the potential for U.S. unilateral action. ${ }^{47}$

In public statements, Administration officials have, at times, expressed divergent assessments of the threat emanating from northern Mali, and of the urgency required to address it. For example, Assistant Secretary of State for African Affairs Johnnie Carson testified before Congress in June 2012 that "AQIM has not demonstrated the capability to threaten U.S. interests outside of West or North Africa and it has not threatened to attack the U.S. homeland," adding that "we are nevertheless working to counter its influence." In contrast, General Carter Ham, the commander of U.S. Africa Command, has stated that AQIM "aspire[s] to conduct events more broadly across the region, and eventually to the United States," and Assistant Secretary of Defense Michael Sheehan has said of Mali that "we cannot allow al Qaeda to sit in ungoverned places." Defense Secretary Leon Panetta stated in December that "the main goal of Al Qaeda is to attack the United

\footnotetext{
${ }^{43}$ The regional CAP is for the countries of Mali, Burkina Faso, Cameroon, Chad, Mauritania, Niger, Nigeria, Senegal, and The Gambia. As of late 2012, about 32\% of the 2012 CAP for the Sahel remained unmet, amid competing appeals for sizable humanitarian aid for Syria, the Democratic Republic of Congo, and other crises. UNOCHA, Sahel Crisis 2012: Funding Status as of 23 Nov. 2012.

${ }^{44}$ USAID, Mali-Humanitarian Update \#4, December 13, 2012.

${ }^{45}$ State Department daily press briefing, November 20, 2012; U.S. Africa Command, "General Ham Discusses Security Challenges, Opportunities at George Washington University," December 7, 2012.

${ }^{46}$ Assistant Secretary of State for African Affairs Johnnie Carson, testimony before the Senate Foreign Relations Subcommittee on African Affairs, "Assessing Developments in Mali: Restoring Democracy and Reclaiming the North," December 5, 2012.

${ }^{47}$ See, e.g., Greg Miller and Craig Whitlock, "White House Secret Meetings Examine Al-Qaeda Threat in North Africa," Washington Post, October 1, 2012
} 
States... And if we're not going to allow it to happen, we've got to go after them in Yemen, in Somalia and yes, in Mali if necessary."

The potential for U.S. citizens to join or directly finance terrorist groups in the Sahel appears to be relatively low. Still, on December 13, 2012, a U.S. District Court indicted two U.S. citizens who had, according to the Federal Bureau of Investigations (FBI), attempted unsuccessfully to travel to Mauritania, potentially to join jihadist groups in northern Mali. The two are charged with material support to terrorists and false statements in the application and use of a passport. ${ }^{49}$

U.S. diplomatic engagement has focused on the political crisis in Bamako in light of concerns that without a credible, legitimate, effective government and military, it will be difficult for the Malian state to lead operations in the north or implement a peace deal. ${ }^{50}$ Among international and regional actors, the United States has been the most vocal in emphasizing the need for elections in the near term. The Administration has called for elections before the interim government's mandate expires in April 2013, or as soon as possible. ${ }^{51}$ Many Malians object to the idea of holding elections without the north, even if the vast majority of the population is located in the south, and even if voting could be held among displaced northerners. ${ }^{52}$ The Obama Administration has also attempted to isolate individuals who supported the 2012 military coup, including via a visa ban on over 60 people associated with the former junta. ${ }^{53}$

Prior to French military operations, Administration officials had paired broad support for proposed African-led military intervention with expressions of concern over the capacity of potential regional troop contributors and over the possible unintended consequences of such an operation. Some of the concerns expressed were significant enough to call into question whether the Administration viewed the proposal for a regional military intervention as potentially counterproductive. In early December (two weeks prior to U.N. Security Council authorization of AFISMA), Assistant Secretary of State Carson testified before Congress that

[S]everal key questions must be answered to ensure that this effort is also well-planned and well-resourced. These issues include outstanding questions about necessary force levels, the capabilities of the Malian and international forces to accomplish the objectives of the mission, cost and funding needs, logistical requirements, operational timelines, planning for minimizing impacts on civilian security and the humanitarian situation, and ensuring that the proposed military action is adequately linked to a sufficiently detailed political strategy and end-state for military operations in the north. ${ }^{54}$

\footnotetext{
${ }^{48}$ Assistant Secretary of State Carson, testimony before the House Foreign Affairs Subcommittee on Africa, Global Health, and Human Rights, June 29, 2012; Adam Entous and Drew Hinshaw, "U.S. Sets Sights on Al Qaeda in Mali," Wall Street Journal, July 27, 2012; Wall Street Journal, "Terror Fight Shifts to Africa," op. cit.; and CNN, "Panetta on Al Qaeda in Mali," December 13, 2012.

${ }^{49}$ U.S. District Court for the Southern District of Alabama, Criminal Complaint, United States of America $v$. Mohammad Abdul Rahman Abukhdair and Randy Wilson, aka Rasheed Wilson.

${ }^{50}$ AllAfrica.com, "Restore Democracy Then Liberate the North - U.S. Official Johnnie Carson," October 1, 2012.

${ }^{51}$ State Department, Statement by Victoria Nuland, Spokesperson, October 12, 2012; State Department daily news briefing, December 12, 2012.

${ }^{52}$ See Report of the Secretary-General on the Situation in Mali, op. cit. The report states that one option may be to hold a vote in some parts of the north, presumably as an outcome of negotiations with certain armed groups.

${ }^{53}$ Assistant Secretary of State Carson testimony before the Senate, op. cit.

${ }^{54}$ Carson testimony before the Senate Foreign Relations Subcommittee on African Affairs, December 5, 2012.
} 
The United States has provided military planners to assist ECOWAS and the AU in developing AFISMA's concept of operations. Direct U.S. assistance to the Malian security forces is currently prohibited (see below). In recent months, the Administration has provided new counterterrorism and border security assistance to states neighboring Mali. The recipient countries are-like Mali-participants in the U.S. interagency, multiyear, regional counterterrorism initiative, the Trans-Sahara Counter-Terrorism Partnership (TSCTP) (discussed below).

\section{U.S. Foreign Assistance}

Prior to the coup, the United States was one of the largest bilateral donors to Mali, with aid programs focusing on food security, health, education, governance, counterterrorism, and military professionalization. Many types of U.S. bilateral foreign aid for Mali are now prohibited under Section 7008 of the FY2012 Consolidated Appropriations Act, P.L. 112-74, which bars State Department and USAID-administered aid to the government of any country in which a military coup or decree has overthrown a democratically elected government. ${ }^{55}$

The coup-related restrictions do not apply to humanitarian aid, which has been defined, in the case of Mali, to include bilateral health and food security aid. The United States is the leading provider of emergency humanitarian aid in Mali and the region, having allocated over $\$ 445.9$ million in humanitarian assistance to the Sahel region in FY2012 and FY2013 to date. Of this, $\$ 119.3$ million has been provided for drought- and conflict-affected Malians. ${ }^{56}$

The prohibition in Section 7008 refers to assistance implemented in coordination with the Malian government. U.S. security assistance programs have therefore been suspended. Mali's \$461 million Millennium Challenge Corporation (MCC) compact — which focused on improving agricultural development along the Niger River and constructing a new international airport in Bamako-has been terminated, months before its slated completion. The Administration has also suspended some potentially legally permissible programs, including security cooperation activities administered by the Defense Department, due to policy concerns. ${ }^{57}$ Still, about $\$ 70.4$ million in bilateral foreign assistance, in addition to the emergency humanitarian aid cited above, has either continued under existing legal authorities, or has been approved to resume. ${ }^{58}$

\footnotetext{
${ }^{55}$ Similar provisions have been included in annual foreign operations appropriations legislation since at least 1985, and have been carried over into FY2013 via continuing resolution. Section 7008 reads: "None of the funds appropriated or otherwise made available pursuant to titles III through VI of this Act shall be obligated or expended to finance directly any assistance to the government of any country whose duly elected head of government is deposed by military coup d'etat or decree or, after the date of enactment of this Act, a coup d'état or decree in which the military plays a decisive role: Provided, That assistance may be resumed to such government if the President determines and certifies to the Committees on Appropriations that subsequent to the termination of assistance a democratically elected government has taken office: Provided further, That the provisions of this section shall not apply to assistance to promote democratic elections or public participation in democratic processes." Humanitarian aid accounts are exempt due to the authorities governing their appropriation.

${ }^{56}$ USAID, Mali-Humanitarian Update \#4, December 13, 2012.

${ }^{57}$ Deputy Assistant Secretary of Defense Amanda Dory testimony before the Senate, op. cit.

${ }^{58}$ State Department response to CRS query, November 2012. About $\$ 247$ million in cumulative foreign aid funding that would have gone to Mali has been terminated, suspended, or placed on operational hold due to the combination of legal and policy restrictions. (This is in addition to terminated MCC funds.) Another $\$ 4.1$ million has been redirected to other countries.
} 
Prior to the coup, Mali was a relatively significant beneficiary (by regional standards) of U.S. security assistance as a focus country of TSCTP, and of security cooperation through the Defense Department's Operation Juniper Shield. ${ }^{59}$ The Defense Department's flagship multinational military exercise in the Sahel, known as Flintlock, was due to be held in Mali in February 2012, but was canceled due to the MNLA conflict that was then raging in the north. Administration officials have acknowledged that the suspension of security assistance may detract from the Malian army's capacity to redeploy in the north. ${ }^{60}$

\section{The Trans Sahara Counter-Terrorism Partnership: Background and Policy Debates}

The interagency Trans Sahara Counter-Terrorism Partnership (TSCTP) aims to counter violent extremism in NorthWest Africa through a range of security assistance, development, and governance-focused activities. The goal has been to design multi-faceted programs that take into account the region's complex developmental and security context. Under Operation Juniper Shield (formerly Operation Enduring Freedom-Trans Sahara), which complements TSCTP, U.S. military forces work with their regional counterparts to improve intelligence, regional coordination, logistics, border control, and targeting. State Department- and USAID-administered funding for TSCTP is estimated at about $\$ 52$ million in FY2012, drawn from multiple accounts; the annual budget for Operation Juniper Shield is about $\$ 46$ million.61 Other assistance, such as Defense Department-administered "Section 1206" global train-and-equip funds, also contributes to TSCTP. TSCTP is a successor to the 2002-2004 Pan Sahel Initiative, which focused on Mali, Mauritania, Niger, and Chad. TSCTP was launched in 2005 and expanded the list of partner countries to a total of 10 , including Algeria, Burkina Faso, Morocco, Nigeria, Senegal, and Tunisia.

Although TSCTP aims to take a holistic approach to countering violent extremism, the program has suffered since its inception from challenges in establishing a comprehensive strategic design, transcending a more traditional bilateral style of foreign assistance, ensuring interagency coordination, and evaluating outcomes. ${ }^{62}$ As the Mali situation illustrates, the disruption of funds due to political or human rights concerns in partner countries presents a challenge to program continuity and capacity building efforts. Mali is the third TSCTP focus country to undergo a military coup since 2008 (after Mauritania and Niger); these coups have each caused disruptions in U.S. engagement and have led some to question TSCTP's effectiveness in promoting stability and civilian control of the armed forces. Some critics have also accused TSCTP of focusing on military assistance to the detriment of other types of U.S. engagement, resulting in what critics allege has been a "militarization of U.S. policy" in the region or a misbalancing of U.S. resources. ${ }^{63}$ The expansion of AQIM and associated groups in northern Mali has also led some observers to question TSCTP's ability to counter the regional spread of terrorism and extremist ideology.

\section{Outlook}

Congress may consider issues related to whether or how the United States might support French and regional military operations in Mali; potential U.S. support for African states seeking to deploy under AFISMA; U.S. aid to Mali and the region, including humanitarian assistance in response to evolving needs in the Sahel; and oversight of U.S. regional policy and actions.

\footnotetext{
${ }^{59}$ This was previously known as Operation Enduring Freedom-Trans Sahara, or OEF-TS, and is part of the Defense Department's North West Africa Campaign. Defense activities under the operation complement TSCTP.

${ }^{60}$ State Department daily news briefing, March 23, 2012.

${ }^{61}$ State Department, Congressional Budget Justification, Foreign Operations, FY2013; CRS Report RL34003, Africa Command: U.S. Strategic Interests and the Role of the U.S. Military in Africa, by Lauren Ploch Blanchard.

${ }^{62}$ See Government Accountability Office (GAO), Actions Needed to Enhance Implementation of Trans-Sahara Counterterrorism Partnership, GAO-08-860, July 31, 2008. A 2011 evaluation of USAID's counter-extremism programs under TSCTP suggested that the impact has been positive but limited. USAID, Mid-Term Evaluation of USAID's Counter-Extremism Programming in Africa, February 1, 2011.

${ }^{63}$ See, for example, Concerned Africa Scholars, US Militarization of the Sahara-Sahel Security, Space \& Imperialism, Spring 2010; Ron Capps, Drawing on the Full Strength of America: Seeking Greater Civilian Capacity in U.S. Foreign Affairs, Refugees International, September 2009; and ICG, Islamist Terrorism in the Sahel: Fact or Fiction? op. cit.
} 
Congress may also consider the possible implications of the situation in Mali for the design, emphasis, and evaluation of U.S. policy efforts in the region and beyond.

International policymakers face complex challenges in addressing the situation in Mali, because the threads of Mali's political and security crises are intertwined, and are also tied to a difficult regional context. Notably, given the Malian military's internal problems and capacity shortfalls, it is unclear whether Malian forces will be able or willing to follow French military strikes by securing and holding territory liberated from insurgent groups. Similar concerns apply to probable regional troop contributors, who face significant capacity, logistics, and financial shortfalls. International military operations could also prompt a backlash among northern communities, terrorist attacks by extremists, or additional frictions within the Malian military. Overall, the conditions under which the north could conceivably be reintegrated into the Malian state in a sustainable way remain unclear, and the path to achieving such an outcome uncertain.

U.S. policymakers are likely to continue to debate the merits, legal authority, and potential unintended consequences of counterterrorism activities in Mali and the Sahel. In weighing the often conflicting reports with regard to the regional presence of AQIM and other violent extremist groups, congressional actors may examine the extent to which these groups pose a threat to U.S. targets and interests. Mali's situation can also be examined in the context of ongoing efforts to measure the effectiveness of U.S. policies and aid programs aimed at enhancing regional stability, good governance, and counterterrorism capacity in Africa and beyond.

Emerging policy questions include

- What are the likely scope and duration of French - and potentially other international-operations in Mali, and what end-state do these operations seek? To what extent are any security gains likely to be durable? To what extent is the Malian military able and willing to secure and hold territory cleared by French (and potentially other international) military strikes? What are the prospects for restoring Mali's "territorial integrity and unity," a key goal of international policy efforts under U.N. Security Council Resolution 2085? What are the likely repercussions of the ongoing military operations for regional security and humanitarian conditions?

- What role might the United States play in nascent French and regional military operations in Mali? What budgetary and other resources are available for the various courses of U.S. action? What is the relative importance of the situation in Mali compared to other U.S. policy priorities and national security concerns?

- Do AQIM and loosely allied extremist groups in northern Mali primarily pose a threat to regional security, or do they pose a more direct threat to the United States? What is the likely short-term impact of international military operations in Mali on the level of threat these groups pose to U.S. interests?

- How are AQIM and affiliated groups reacting to international military strikes? What are their military capabilities? While many Malians have been outraged at the harsh punitive measures instituted by Islamist extremist groups in the north, to what extent do these groups benefit from any local support? What types of external support do they receive?

- What is the likely timeframe for Malian national elections, and under what conditions would elections be perceived as credible? In the interim, should the 
legal and policy restrictions on U.S. security assistance and cooperation for the Malian security forces be revised, or maintained? What are the implications of coup leader Capt. Sanogo's continued interference in Malian politics and role in security sector reform?

- What are the capabilities and commitment of the likely African troop contributors to AFISMA? What are the policy and funding lessons learned from U.S.supported, African-led military operations elsewhere on the continent, including in Somalia, Darfur, and Liberia? What is the AFISMA operation in Mali likely to cost, and what is the appropriate U.S. contribution? What is the likely impact of international training - such as the planned European Union mission-on the cohesiveness and behavior of the Malian military?

\title{
Author Contact Information
}

\author{
Alexis Arieff \\ Analyst in African Affairs \\ aarieff@crs.loc.gov, 7-2459
}

\section{Acknowledgments}

Kelly Johnson, former CRS Research Associate; Hannah Fischer of the CRS Knowledge Services Group; and Amber Wilhelm, of CRS Graphics, contributed to this report. 